\title{
A CONTROLLED STUDY OF AN HIV/AIDS/STI/TB INTERVENTION WITH FAITH HEALERS IN VHEMBE DISTRICT, SOUTH AFRICA
}

\author{
Tshilidzi Mashamba, ${ }^{a}$ Karl Peltzer, ${ }^{* b}$ Thelma X. Maluleke, ${ }^{c}$ and Tholene Sodi ${ }^{d}$
}

\author{
${ }^{a}$ Department of Psychology, University of Venda, Thohoyandou, South Africa \\ ${ }^{b}$ Social Aspects of HIV/AIDS and Health, Human Sciences Research Council, Pretoria, South Africa \\ \& Department of Psychology, University of the Free State, Bloemfontein, South Africa. \\ ${ }^{\mathrm{c}}$ Faculty of Health Sciences, Walter Sisulu University, Umtata, South Africa \\ ${ }^{\mathrm{d}}$ Department of Psychology, University of Limpopo, Turfloop campus, Sovenga, South Africa. \\ *Email: kpeltzer@hsrc.ac.za
}

\begin{abstract}
The aim of the study was to develop an HIV and AIDS training manual, and to evaluate the knowledge, attitudes and management of faith healers of Apostolic churches regarding HIV and AIDS, before and after they attended an HIV and AIDS training programme. A quasi-experimental intervention design was used with faith healers affiliated with the United African Apostolic Church (UAAC) in the Thulamela and Musina municipalities of Vhembe District, Limpopo Province, South Africa. A total of 103 faith healers were included in this study, 58 were systematically assigned to an intervention and 45 to a control group. The intervention group received training for 2 days. At follow-up after 2 months, intervention effects were significant for HIV knowledge and to a lesser extent TB knowledge. No significant improvement was found in HIV/STI (sexually transmitted infection) management strategies such as HIV/STI risk behaviour counselling, referral of clients for HIV testing, keeping condoms at stock in church, and church community HIV/AIDS/STI education. It is important to note that faith healers address some of the major known behavioural risk and protective factors such as partner reduction and condom use. Therefore, faith healers could be more widely utilized in HIV prevention programmes as risk reduction counsellors, in particular on matters of community-level education.
\end{abstract}

Key words: HIV/AIDS/STI, controlled evaluation, intervention, faith healers, South Africa

\section{Introduction}

There is an estimated 5.5 million people living with HIV in South Africa (UNAIDS, 2008). Young women are disproportionately affected, with incidence rates amongst women aged 20-29 years, 6 fold higher (5.6\%) than that of males (0.9\%) (Rehle et al., 2007). South Africa is facing challenges on how to effectively address the impact of the HIV and AIDS pandemic. Different institutions, such as governments, non-governmental organisations (NGOs), businesses and individuals in the private sector and churches have joined forces in trying to combat the pandemic.

Traditional healers who practice in South Africa can broadly be grouped into three types; the traditional doctor or inyanga who is typically male and uses herbal and other medicinal preparations for treating disease (or herbalist); the isangoma (Zulu) or diviner, usually a woman who operates within a traditional religious supernatural context and acts as a medium with the ancestral shades; and the faith healer who integrates Christian ritual and traditional practices (Freeman and Motsei, 1992). For the purpose of this study, the following operational definition will be used: A faith healer is any Christian who believes in faith healing and who is also a member of a church that practises faith healing. Different health practitioners, indigenous- and faith healers have been using a variety of techniques in order to treat, prevent and manage HIV and AIDS. This disease does not only affect the infected people, but also their families, friends, and their whole communities (Barnett and Whiteside, 2002). Traditional health practitioners in South Africa can include the following categories: Diviners (Izangoma/Amagqirha), Herbalists (Izinyanga/amaxhwele), Prophets/faith healers (abaprofeti/abathandazeli), Traditional surgeons (iingcibi), and Traditional birth attendants (ababelethisi/abazalisi) (Gqaleni et al., 2007). A faith healer in this context is a Christian who may belong either to a Christian mission or an independent church (West, 1975).

During the early years of the HIV and AIDS pandemic, many people who worked in HIV and AIDS prevention institutions believed religious leaders and faith-based organizations (FBOs) and churches were naturally antagonistic to what they were trying to accomplish. Many perceived the typical religious leader as a conservative moralist who disapproved of any form of sexual behaviour outside of marriage, to say nothing of non-standard sexual practices. It was also believed or known that religious leaders disapproved of condom use (which is considered one of the best way to prevent HIV infection), and organized religion was seen as an impediment to sex education in schools (Green, 2003). It was recognized that the sexual nature in which HIV is most often contracted posed a problem for the church. Sex, sin, shame and stigma have caused many churches to remain publicly silent about HIV and AIDS. This stance, combined with the many existing cultural taboos 
against open dialogue about sexual matters, has been an obstacle to the dissemination of messages about the protection from and prevention of HIV and AIDS. This is why most churches in South Africa have been more involved in the care and support programmes for HIV and AIDS victims and less involved in the HIV and AIDS prevention strategies (Green, 2003). Merz (1997) comments that one of the roles of the church in helping prevent HIV and AIDS is to preach messages about health care, sexuality, reproduction, family life, morality, and to provide members with a holistic understanding of healing and spirituality. Studies involving church members found little on HIV issues. In a study by Skhosana (2000) on HIV and AIDS, he found that $66.6 \%$ of the respondents said they had never heard a sermon on HIV and AIDS, $28.6 \%$ had seldom heard a sermon on HIV and AIDS, and only $4.8 \%$ had heard regular sermons on HIV and AIDS. This explains why some Christians do not get involved in HIV and AIDS issues because the church is silent. The problem is that even if it is included in a sermon, there will be those church members who would oppose it, since HIV is always associated with sex and, in turn, sex is linked with sin.

A similar problem was experienced by the Full Gospel Church of God in Gugulethu. Byamugisha et al., (2002) reported that Rev. Gideon Nqiwa of the abovementioned church introduced the idea of an AIDS programme in 2000 in his church. A lot of people felt very uncomfortable because they felt that AIDS and sex were not issues to be discussed in church. Their position changed when an HIV positive young man from the Treatment Action Campaign came to speak during a Sunday service. He told them that he had carried the HIV Virus. His presentation was very emotional and some people cried, while others went to hug him and prayed for him. And that was when the congregation became supportive of the AIDS programmes. It is important for Christians to become involved in HIV and AIDS issues and to learn as much as they can about this disease in order to assist in fighting against its spread. Repicky (1988) advised that Christians need to learn valuing knowledge over ignorance, and to start assuming the responsibility for directing their own self-development through insights gained from that knowledge in humble and intimate companionship with God. Inviting People Living with AIDS (PLWA), Aids activists, high profile people and renowned priests, role models and celebrities to give speeches to church members would help to change people's attitudes. Having gospel songs and gospel concerts that inform the public about HIV and AIDS is another possible strategy.

\section{Faith communities in South Africa}

According to figures on religious demography from the (last) 2001 census in South Africa (Stats SA, 2003), approximately 84 percent of the population belongs to the Christian faith, and 4 percent to other religions, including Hinduism (1.2 percent), Islam (1.5 percent), Judaism ( 0.2 percent), and traditional African beliefs ( 0.3 percent). The African Independent Churches (AIC) are the largest group of Christian churches. There are about 4,000 such congregations and with a total membership of more than 10 million believers. Although these churches originally were founded as breakaways from various mission churches (the so-called Ethiopian churches), the African Independent Churches now consist mostly of Zionist or Apostolic churches and also include some Pentecostal branches (Anderson, 2000; Stats SA, 2003).

Various intervention strategies have been adopted to educate traditional healers in the fundamentals of Sexually Transmitted Infection (STI) and HIV medicine (Sorsdahl et al. 2009). To our knowledge, however, no study has thus far been attempted to determine whether interventions to educate faith healers in HIV and STI medicine result in an increase in knowledge. Therefore, the aim of this study was to develop an HIV and AIDS training manual for faith healers of Apostolic churches specifically, and to then evaluate the knowledge of faith healers regarding HIV and AIDS, before and after they attended an HIV and AIDS training programme using the manual.

\section{Method \\ Study design and setting}

We used a quasi-experimental intervention design with faith healers. The study included faith healers who were all affiliated with the United African Apostolic Church (UAAC) in the Thulamela and Musina municipalities of Vhembe District, Limpopo Province, South Africa. Members of the UAAC are Christians who believe in and practice faith healing; One of the activities during church services is praying for the sick, using different strategies such as the laying on of hands, sprinkling water, and wearing a rope - which has been prayed for - around the waist; Different church members can pray for the sick including a superintendent, an inspector, a priest, a juffrou (female adult), a prophet, and ordinary church members.

\section{Sample and procedure}

A total of 103 faith healers were included in this study, 58 were randomly assigned to an intervention and 45 to a control group. Faith healers were contacted through existing lists of United African Apostolic churches. This study was approved by the Research Ethics Committee of the University of Venda and individual faith healers belonging to the United African Apostolic Church (UAAC) consented to the study. Almost all faith healers were Venda (89.3\%) by ethnicity. Most faith healers (86.2\%) were females in the experimental arm and two-thirds (64.4\%) were female in the control arm. There were more faith healers who were older and with less education in the intervention as compared to the control arm (Table 1), \{the procedure was at random, yet results seem to differ regarding the demographics indicated\}. 
Table 1: Sample characteristics of Apostolic faith healers

\begin{tabular}{|c|c|c|c|c|c|c|}
\hline \multicolumn{2}{|c|}{ Biographical item } & \multicolumn{2}{|c|}{$\begin{array}{c}\text { Control } \\
(n=45)\end{array}$} & \multicolumn{2}{|c|}{ Experimental $(n=58)$} & \multirow[b]{2}{*}{$\chi^{2}$} \\
\hline & & $\mathbf{N}$ & $\%$ & $\mathbf{N}$ & $\%$ & \\
\hline Gender & $\begin{array}{l}\text { Male } \\
\text { Female }\end{array}$ & $\begin{array}{l}16 \\
29\end{array}$ & $\begin{array}{l}35.6 \\
64.4\end{array}$ & $\begin{array}{c}8 \\
50\end{array}$ & $\begin{array}{l}13.8 \\
86.2\end{array}$ & $6.72 *$ \\
\hline Age & $\begin{array}{l}\text { Below } 30 \\
30-39 \\
40-59 \\
60+\end{array}$ & $\begin{array}{c}25 \\
12 \\
5 \\
3\end{array}$ & $\begin{array}{c}55.6 \\
26.7 \\
11.1 \\
6.7\end{array}$ & $\begin{array}{l}11 \\
12 \\
19 \\
16\end{array}$ & $\begin{array}{l}19.0 \\
20.7 \\
32.8 \\
27.6\end{array}$ & $21.20 * * *$ \\
\hline Education & $\begin{array}{l}\text { No Schooling } \\
\text { Primary } \\
\text { Secondary } \\
\text { Post-secondary }\end{array}$ & $\begin{array}{c}5 \\
9 \\
18 \\
1\end{array}$ & $\begin{array}{c}11.9 \\
21.4 \\
42.9 \\
1.8\end{array}$ & $\begin{array}{l}16 \\
24 \\
16 \\
10\end{array}$ & $\begin{array}{l}28.1 \\
42.1 \\
28.1 \\
23.9\end{array}$ & $23.72 * *$ \\
\hline
\end{tabular}

Questionnaires were interview-administered in Venda by two research assistants trained in administration of this interview schedule. Questionnaires were translated from English to Venda by one staff of Department of Lexicography at the University of Venda and back translated by another. Prior to the interview, each participant was informed about the anonymous procedures used in the study. To assure anonymity of responses, participants' names did not appear on any measures, and all data tracking was accomplished through a number-coding system.

\section{Experimental intervention}

The intervention condition received training for two days per group by the researcher. After two months, the posttest questionnaire was administered to both groups. The training manual was modified from one designed by the Human Sciences Research Council for traditional healers (Dlamini et al., 2004). The instruction in the training was a combination of lectures, question and answer sessions and group discussions. The training was conducted in Venda. Almost all faith healers were Venda (89.3\%) by ethnicity and questionnaires were interview-administered in Venda yet the training was conducted in Venda. The following modules were offered:

Module 1: $\quad$ HIV and AIDS

Module 2: $\quad$ Sexually Transmitted Infections

Module 3: $\quad$ How to manage STI/HIV/AIDS

Module 4: $\quad$ HIV/AIDS and family planning

Module 5: $\quad$ Tuberculosis

Module 6: $\quad$ Nutrition

Module 7: $\quad$ Infection control

Module 8: $\quad$ Danger signs and symptoms

Module 9: $\quad$ HIV/AIDS and mental illness.

Training was done using the Information-Motivation-Behaviour Skills (IMB) model of STI/HIV risk behaviour change. According to Fisher (1997:105), the IMB model "proposes that information that is directly relevant to the personal practice of preventative behaviour, motivation to practice prevention, and behaviour skills for practicing prevention effectively, are the fundamental determinants of STI/HIV preventive behaviour". Thus this theory suggests that there are people who are at risk because they have insufficient information about the personal practice of preventive behaviour, insufficient personal and social motivation to practice prevention, and inadequate behavioural skills for practicing prevention effectively. It has been found that prevailing high levels of STI/HIV risk are the result of this situation. On the basis of this analysis, the theory designates three areas - information, motivation, and behavioural skills - as critical factors to target in intervention efforts to promote preventive behaviour (Fisher, 1997). In this study, the information included the nature of HIV and AIDS, STIs, STI/HIV transmission, condom use, HIV testing and family planning methods. The motivational content included materials designed to increase the participants' awareness of their personal risk of infection and the risk of their patients. No training was given in behavioural skills.

\section{Control condition}

Participants assigned to the control condition completed assessments during the same periods as intervention participants, but they received no training but only an information booklet after the follow-up assessment interview. 


\section{Measure}

The questionnaire used was adapted from previous studies (Peltzer et al. , 2006), comprised of the following six components: Biographical data (8 items); Faith healer's practice characteristics (10 items); Risk perception and attitudes (4 items); HIV/STI management related questions (5 items); HIV/AIDS/STI knowledge questions (12 items); and TB knowledge questions (6 items). Response options were for the knowledge questions true, false or do not know, and response options for all other questions were "yes" or "no". The 12-item HIV/AIDS knowledge index was internally consistent, alpha $=.86$ as was the 6-item TB knowledge index, alpha $=.81$. However, the 5-item HIV/STI management practices index had a moderate consistency, alpha=.60.

\section{Data analysis}

Descriptive statistics was used to obtain frequency distributions, Pearson's Chi-square, ANOVA and independent samples $t$-tests analysis of differences between groups using SPSS version 17.0. The outcome measures such as HIV/AIDS/STI knowledge score served as the dependent variable and were analysed by means of a 2 x 2 repeated measures of analysis of variance (ANOVA), with Time (pretest-posttest) being within factor and Group (experimental-comparisons) being the between factor.

\section{Results}

Of the 103 faith healers in the study, all completed the two months follow-up interview.

\section{Practice characteristics of faith healers}

In both experimental and control groups most faith healers full-time practitioners (67.9\% in the experimental and $47.5 \%$ in the control group). The age at which faith healers started practicing was younger in the control group (82.2\% were less than 30 years) than in the experimental group ( $58.7 \%$ were less than 30 years). The number of sick people who come for consultation in a month was slightly higher in the experimental group (more than $30=34.6 \%, 6-30=31.8 \%$ and $0-5=34.6 \%$ ) than in the control group (more than $30=25.0 \%, 6-30=22.0 \%$ and $0-5=53.0 \%$ ).

Faith healers were asked at pre-intervention about the five most common conditions they treated; the most commonly treated conditions were chest pain (55.9\%), followed by cancer (31.4\%), headache (21.6\%), diarrhoea (18.6\%), STIs (15.7\%), stomach ulcer (13.7\%), cholera (13.7\%), vomiting (11.8\%), high blood pressure (9.8\%), infertility (9.8\%), painful or swollen legs (8.8\%), painful waist (7.8\%), coughing (6.9\%), evil spirit (6.9\%), TB (6.9\%), dizziness (5.9\%), heart problems (5.9\%), tiredness (5.9\%), HIV and AIDS (5.9\%).

\section{HIV, AIDS, STI, and TB knowledge}

Although most faith healers had correct knowledge of the major HIV transmission routes ANOVA controlling for pre-intervention differences found a significant intervention effect for HIV knowledge ( $\mathrm{F}=8.79, \mathrm{P}<.05)$. Regarding TB knowledge, almost all faith healers agreed that TB is curable and correctly said that the treatment takes 6 to 8 months. At baseline less than two-thirds of the faith healers knew the transmission route that is breathing the air around a person who is sick with TB; many had misconceptions about TB transmission, such as believing one can get TB from mosquito or other insect bites. An ANOVA controlling for pre-intervention differences did not find a significant intervention effect for TB knowledge $(\mathrm{F}=0.79$, ns). The percentage of those who knew that TB could be spread by sharing eating or drinking utensils with a person suffering from TB increased in both the control group (55.8\% pre-, 88.6\% post-), and the experimental group (73.2\% pre-, $84.1 \%$ post-) (Table 2 ).

\section{HIV/STI management}

The majority of the faith healers knew or had improved knowledge of where to obtain HIV voluntary counselling and testing. More than half of the faith healers indicated that they had referred a client for HIV testing in the past three months. For the HIV/STI management strategies faith healers in the intervention group did not significantly improve in terms of conducting risk reduction counselling, talking about HIV/AIDS/STI and keeping condoms at stock in church. An ANOVA controlling for pre-intervention differences found no significant intervention effect for HIV/STI management practices (Table 3).

\section{HIV risk perception and attitudes}

At pre-intervention most faith healers (74\% in the experimental and $75 \%$ in the control group) did not feel at risk for HIV when praying or healing a client, while at follow-up most faith healers (53.7\% in the experimental and $77.1 \%$ in the control group) felt at great risk for HIV when praying or healing a client At pre- and post intervention more than threequarters of the faith healers felt at great risk of getting HIV in their personal life. At pre-intervention most faith healers ( $86.4 \%$ in the experimental and $97.3 \%$ in the control group) and at post intervention all faith healers approved of distributing condoms. More than two-thirds of the faith healers used condoms themselves (Table 4). 
Table 2: HIV/AIDS/STI and tuberculosis knowledge in correct responses (The response options "True” were rated " 1 ” and "False" or "Do not know" as "0")

\begin{tabular}{|c|c|c|c|c|}
\hline & \multicolumn{2}{|c|}{ Pre (\%) } & \multicolumn{2}{|c|}{ Follow-up (\%) } \\
\hline HIV/AIDS/STI knowledge items & $\begin{array}{c}\operatorname{Exp} \\
(\mathrm{n}=58)\end{array}$ & $\begin{array}{c}\text { Con } \\
(\mathrm{n}=45)\end{array}$ & $\begin{array}{c}\operatorname{Exp} \\
(\mathrm{n}=58)\end{array}$ & $\begin{array}{c}\text { Con } \\
(\mathrm{n}=45)\end{array}$ \\
\hline $\begin{array}{l}\text { A person can get HIV by using a cup or plate that has been used by a } \\
\text { person with HIV/AIDS (false) }\end{array}$ & 74.1 & 86.4 & 91.3 & 100 \\
\hline Having sex with a virgin can cure HIV/AIDS (false) & 82.1 & 78.0 & 91.1 & 100 \\
\hline A person can be infected with HIV and still look healthy (true) & 65.4 & 68.2 & 56.8 & 30.0 \\
\hline $\begin{array}{l}\text { People can protect themselves from HIV by using a condom correctly } \\
\text { every time they have sex (true) }\end{array}$ & 86.2 & 93.2 & 89.1 & 95.0 \\
\hline You can get HIV through contact with infected blood (true) & 84.2 & 73.8 & 100 & 100 \\
\hline $\begin{array}{l}\text { A person can get HIV from oral sex (mouth-to-penis or mouth-to- } \\
\text { vagina) (true) }\end{array}$ & 54.4 & 66.7 & 65.2 & 50.0 \\
\hline $\begin{array}{l}\text { HIV can be transmitted from mother to child through breast feeding } \\
\text { (true) }\end{array}$ & 74.1 & 85.7 & 97.8 & 97.5 \\
\hline $\begin{array}{l}\text { Once one has started taking antiretroviral treatment for HIV/AIDS one } \\
\text { has to take it forever (true) }\end{array}$ & 69.0 & 83.7 & 76.1 & 67.5 \\
\hline Dry sex increases the risk of sexually transmitted infections (true) & 42.6 & 48.8 & 62.8 & 76.9 \\
\hline Can the transmission of HIV from mother to child be prevented (true) & 75.0 & 83.7 & 97.7 & 100 \\
\hline Can needles and razors transmit HIV (true) & 83.9 & 76.7 & 100 & 97.4 \\
\hline There is no cure for HIV, the virus that causes AIDS (true) & 65.5 & 66.7 & 84.1 & 92.5 \\
\hline $\begin{array}{l}\text { Total HIV mean (SD) } \\
\text { ANOVA: Mean difference }=.60, \mathrm{~F}=8.79, \mathrm{p}<05\end{array}$ & $8.5(3.3)$ & $9.2(2.5)$ & $10.3(1.5)$ & $\begin{array}{l}10.1 \\
(1.1)\end{array}$ \\
\hline \multicolumn{5}{|l|}{ How is TB contracted or spread and what is the treatment? } \\
\hline Breathing the air around a person who is sick with TB (true) & 52.7 & 58.1 & 65.9 & 86.1 \\
\hline Sharing eating / drinking utensils (true) & 73.2 & 55.8 & 84.1 & 88.6 \\
\hline From mosquito or other insect bites (false) & 45.5 & 46.5 & 66.7 & 22.2 \\
\hline You have to go to hospital to be cured (true) & 91.1 & 92.9 & 100 & 100 \\
\hline Treatment takes years (false) & 74.1 & 53.5 & 86.0 & 91.7 \\
\hline Treatment takes between 6 and 8 months (true) & 80.4 & 71.4 & 90.7 & 94.6 \\
\hline $\begin{array}{l}\text { Total TB mean (SD) } \\
\text { ANOVA: Mean difference }=-.1, \mathrm{~F}=.79 \text {, ns }\end{array}$ & $4.2(1.7)$ & $3.8(1.5)$ & $5.1(0.7)$ & $4.9(0.7)$ \\
\hline
\end{tabular}

Table 3: HIV/STI management in affirmative responses

\begin{tabular}{|l|c|c|c|c|}
\hline & \multicolumn{2}{|c|}{ Pre (\%) } & \multicolumn{2}{c|}{ Follow-up (\%) } \\
\hline & $\begin{array}{c}\text { Exp } \\
(\mathbf{n}=\mathbf{5 8})\end{array}$ & Con (n=45) & $\begin{array}{c}\text { Exp } \\
(\mathbf{n}=\mathbf{5 8})\end{array}$ & $\begin{array}{c}\text { Con } \\
(\mathbf{n}=\mathbf{4 5})\end{array}$ \\
\hline $\begin{array}{l}\text { 1. Do you know where you can obtain voluntary HIV counselling } \\
\text { and testing services? }\end{array}$ & 81.8 & 90.5 & 88.4 & 100 \\
\hline 2. Did you refer a patient for HIV testing in the past 3 months? & 64.2 & 61.0 & 90.7 & 83.8 \\
\hline $\begin{array}{l}\text { 3. Did you do HIV/STI risk reduction counselling (e.g., advice on } \\
\text { condom use, abstinence, and fidelity \& partner reduction) in the } \\
\text { past 3 months? }\end{array}$ & 63.2 & 59.5 & 67.4 & 31.6 \\
\hline $\begin{array}{l}\text { 4. Did you talk about HIV/AIDS/STI in the church in the past 3 } \\
\text { months? }\end{array}$ & 40.4 & 39.5 & 39.5 & 18.4 \\
\hline 5. Did you keep condoms at stock in church in the past 3 months? & 8.2 & 2.9 & 8.8 & 0 \\
\hline $\begin{array}{l}\text { Total mean } \\
\text { ANOVA: Mean difference=0.3, F=.01, ns }\end{array}$ & $2.7(1.3)$ & $2.4(1.3)$ & $2.8(1.1)$ & $2.2(0.7)$ \\
\hline
\end{tabular}


Table 4: HIV risk perceptions and attitudes in percent

\begin{tabular}{|c|c|c|c|c|c|}
\hline & & Pre $(\%$ & & Follon & $(\%)$ \\
\hline & & $\begin{array}{l}\mathbf{E x p} \\
\mathbf{N}=\mathbf{5 8}\end{array}$ & $\begin{array}{l}\text { Con } \\
\mathrm{N}=45 \\
\end{array}$ & $\begin{array}{l}\mathbf{E x p} \\
\mathrm{N}=58\end{array}$ & $\begin{array}{l}\text { Con } \\
\mathrm{N}=45\end{array}$ \\
\hline $\begin{array}{l}\text { How much do you feel at risk of getting HIV } \\
\text { when praying or healing your client? }\end{array}$ & $\begin{array}{l}\text { Great risk } \\
\text { Somewhat at risk } \\
\text { Not at risk }\end{array}$ & $\begin{array}{l}20.5 \\
5.1 \\
74.4\end{array}$ & $\begin{array}{l}19.4 \\
5.6 \\
75.0\end{array}$ & $\begin{array}{l}53.7 \\
2.4 \\
43.9\end{array}$ & $\begin{array}{l}77.1 \\
2.9 \\
20.0\end{array}$ \\
\hline $\begin{array}{l}\text { How much do you feel at risk of getting HIV in } \\
\text { your personal life? }\end{array}$ & $\begin{array}{l}\text { Great risk } \\
\text { Somewhat at risk } \\
\text { Not at risk }\end{array}$ & $\begin{array}{l}76.2 \\
4.8 \\
19.0\end{array}$ & $\begin{array}{l}82.9 \\
2.9 \\
14.2\end{array}$ & $\begin{array}{l}81.8 \\
6.8 \\
11.4\end{array}$ & $\begin{array}{l}94.3 \\
2.9 \\
2.9\end{array}$ \\
\hline Do you approve of distributing condoms? & & 86.4 & 97.3 & 100 & 100 \\
\hline Do you use condoms yourself? & & 61.4 & 88.6 & 69.8 & 94.3 \\
\hline
\end{tabular}

\section{Discussion}

The study found that the most common conditions that patients mentioned were physical problems such as chest pain, cancer, headache, diarrhoea, STIs and stomach ulcer, cholera, vomiting, high blood pressure, infertility, painful or swollen legs, including HIV and social problems and evil spirits. Most of these conditions were similar to those found in other studies on faith healers (Edwards, 1983; Peltzer, 1999; January and Sodi, 2006), and a study on traditional healers (Peltzer et al., 2006). In his study on faith healers, Peltzer (1999) also found that the most commonly treated illnesses included STIs, chest pains, sugar diabetes and high blood pressure.

We implemented and evaluated an HIV/STI education programme for faith healers in rural Vhembe district, South Africa. Following the training faith healers in this study significantly improved their HIV/AIDS and to a lesser extent TB knowledge. Some myths of HIV and in particular TB transmission need to be further emphasized and addressed in trainings programmes. Other studies with traditional healers also found significant improvement of HIV/AIDS knowledge after the training (Peltzer et al., 2006). While 74\% of faith healers felt at risk of HIV infection when praying or healing a client. This significantly reduced after the training. This may be attributed by increased knowledge on how to protect oneself from HIV.

The study found that in the intervention group no significant improvement was found in HIV/STI management strategies such as HIV/STI risk behaviour counselling, referral of clients for HIV testing, keeping condoms at stock in church, and church community HIV/AIDS/STI education. The Information-Motivation-Behaviour Model was used in conducting the training. The training was not long enough to emphasize critical issues such as skills training. It is important to note that faith healers addressed some of the major known behavioural risk and protective factors such as partner reduction and condom use. Therefore, faith healers could be more widely utilized in HIV prevention programmes as risk reduction counsellors, in particular on matters of community-level education. Considering that in this study the faith healers were mostly females, they could possibly provide support to other women, given the gendered nature of the HIV epidemic in South Africa, and the need for strategies to enhance women's ability to protect themselves.

According to the (South African) Department of Health (2004), the continuum of care developed for the HIV and AIDS care and treatment programme should involve traditional health practitioners, and we suggest faith healers too, as an essential and irreplaceable component of the comprehensive care provided. Moreover, traditional health practitioners including faith healers can enhance the implementation of the antiretroviral therapy component of this plan by mobilizing communities, drawing patients into testing programmes, promoting adherence to drug regimens, monitoring side effects, sharing their expertise in patient communications with biomedical practitioners, and vice versa, and continuing their acknowledged mission in improving patient well-being and quality of life. A holistic approach to living with HIV and AIDS is known to be a key factor for success in living a longer, healthy life with the syndrome . Research should be conducted on how faith healers (especially those who are practicing full-time) could fulfil the role of "community HIV/AIDS treatment adherence supporters", either in the form of supporting the directly observed HAART programs and/or as social and emotional support to those receiving treatment.

This study has limitations. The sample of faith healers included in the study was not representative of faith healers in the study area and South Africa. Assessment relied on self-report from faith healers only and did not include onsite checks of HIV prevention activities. Post training assessment was not conducted at different times, i.e. immediately after the training, at 6 and 12 months but only at 2 months following the training. Effects of the training may have faded away after the long time interval. A one-shot training was not sufficient for sustainable effects. This study only included faith healers from the Apostolic church and there is a need to conduct similar programmes and studies with faith healers from other religious groups. 
As a conclusion, faith healers improved and retained their knowledge of HIV/AIDS, even 2 months after their training. They also played an important role giving culturally acceptable STI and HIV/AIDS counselling and community education. Their contribution can be further strengthened by involving them in future HIV/AIDS programmes.

We recommend a more systematic training of faith healers of at least 4 days in South Africa. After initial trainings supervisory and follow up trainings should be conducted. Randomized control trials of HIV interventions should be conducted with faith healers from different churches to further establish their effectiveness in HIV/STI prevention, care and treatment.

\section{Acknowledgements}

Financial support from the University of Venda's Research and Innovation Office to conduct the study is hereby acknowledged.

\section{References}

1. Anderson, A. (2000). The spirituality and experience of Pentecostal and Zionist/Apostolic churches in South Africa. (African Initiatives in Christian Mission No. 6). Pretoria: University of South Africa Press.

2. Barnett, T. and Whiteside, A. (2002). AIDS in the twenty-first century: Disease and globalization. New York: Palgrave Macmillan.

3. Byamugisha, G., Steinitz, L. Y., Williams, G. and Zondi, P. (2002). Journeys of faith: Church-based response to HIV and AIDS in three Southern African countries. Pietermaritzburg: Cluster Publications.

4. Department of Health (2004). Operational plan for comprehensive HIV and AIDS care, management and treatment for South Africa. Pretoria: Department of Health.

5. Dlamini, N., Dlamini, N., Peltzer, K., Mngqundaniso, N., Shangase, M., Buthelezi, D., Petros, G., and Balaba, D. (2004). Traditional healing and STI/HIV/AIDS/TB in South Africa: a trainer's manual for traditional health practitioners, community health workers and nurses. Pretoria: Department of Health \& Bristol-Myers Squibb Foundation,

6. Edwards, F. S. (1983). Healing and transculturation in Xhosa Zionist practice. Culture, Medicine and Psychiatry, 7: 177-198.

7. Fisher, W. A. (1997). A theory-based framework for intervention and evaluation in STD/HIV prevention. The Canadian Journal of Human Sexuality, 6 (2): 105-112.

8. Freeman, M., and Motsei, M. (1992). Planning health care in South Africa: is there a role for traditional healers? Social Science and Medicine, 34: 1183-1090.

9. Gqaleni, N., Moodley, I., Kruger, H., Ntuli, A. and McLeod, H. (2007). Traditional and complementary medicine. South African Health Review, Chapter 12, 175-185. Durban: Health Systems Trust.

10. Green, E. C. (2003). Faith-based organizations: Contributions to HIV prevention. The Synergy Project. USAID.Retrieved at http://www.ccih.org/forum/0110-02.htm, 29 Oct 2009.

11. January, J. and Sodi, T. (2006). The practice of apostolic faith healers in mental health care in Zimbabwe. Journal of Psychology in Africa, 16(2): 315-319.

12. Merz, J. P. (1997). The role of churches in helping adolescents prevent HIV/AIDS. Journal of HIV/AIDS Prevention \& Education for adolescents and children, 1(2), 45-55.

13. Peltzer, K. (1999). Faith healing for mental and social disorders in the Northern Province (South Africa). Journal of Religion in Africa, 29(3): 387-402.

14. Peltzer, K., Mngqundaniso, N. and Petros, G. (2006). A controlled study of an HIV/AIDS/STI/TB intervention with traditional healers in KwaZulu-Natal, South Africa. Aids Behavior, 10(6): 683-690.

15. Rehle, T., Shisana, O., Pillay, V., Zuma, K., Puren, A. and Parker, W. (2007). National HIV incidence measures new insights into the South African epidemic. South African Medical Journal, 97(3): $194-199$.

16. Repicky, R. A. (1988). Jungian typology and Christian spirituality. In R. L. Moore (Ed.) Carl Jung and Christian spirituality (pp. 188-205). New York: Paulist Press.

17. Skhosana, T. J. (2000). A Pentecostal response to the challenges of HIV and AIDS in Tumahole. Masters Thesis in Theology, University of South Africa. Pretoria.

18. Stats SA (Statistics South Africa) (2003). Population census 2001, South Africa. Pretoria: Statistics South Africa.

19. Sorsdahl, K., Ipser, J.C. and Stein, D.J. (2009). Interventions for educating traditional healers about STD and HIV medicine. Cochrane Database Systematic Review, 7(4): CD007190.

20. Statistics South Africa (2003). Population census 2001, South Africa. Pretoria: Statistics South Africa.

21. UNAIDS (2008). Report on the global AIDS epidemic. Geneva: UNAIDS.

22. West, M. (1975). Bishops and prophets in a black city. Cape Town: David Philip. 